\title{
Isolation, characterization, and cytotoxic studies of secondary metabolites from the leaves of Bauhinia foveolata Dalzell: An endemic tree from the Western Ghats, India
}

Prasanna V. Habbu ${ }^{1 *}$, Narayan Miskin ${ }^{1}$, Venkatrao H. Kulkarni², Pradeep Bhat ${ }^{3}$, Arun Joshi ${ }^{4}$, Anant Bhandarkar ${ }^{4}$, Satish Kulkarni $^{5}$, Sheshagiri R. Dixit ${ }^{6}$, Jaishree Vaijanathappa ${ }^{6}$

'Postgraduate Department of Pharmacognosy and Phytochemistry, SET's College of Pharmacy, Dharwad 580 002, India.

${ }^{2}$ Postgraduate Department of Pharmacology, SET's College of Pharmacy, Dharwad 580 002, India.

${ }^{3}$ Indian Council of Medical Research, National Institute of Traditional Medicine, Belagavi 590 010, India.

${ }^{4}$ Department of Pharmacognosy, Goa College of Pharmacy, Panaji, India.

${ }^{5} \mathrm{~B} N$ Degree College, Dandeli 581 325, India.

${ }^{6}$ Department of Pharmaceutical Chemistry, JSS College of Pharmacy, S S Nagar, Mysuru 570015, India.

\section{ARTICLE INFO \\ Received on: 18/10/2019 \\ Accepted on: 23/12/2019 \\ Available online: 05/03/2020}

\section{Key words:}

Bauhinia foveolata,

13-Docosenamide,

flavonoids, cytotoxicity.

\begin{abstract}
Bauhinia foveolata Dalzell is an endemic tree, native to Southwest India (the Western Ghats). 13-Docosenamide was isolated from ethyl acetate fraction, and quercetin (1), isorhamnetin (2), and odoratin-7-glucoside (3) were isolated from butanol fraction of leaves. A spectroscopic analysis, including mass spectra and Nuclear Magnetic Resonance (NMR), and also comparison with reported data were used to elucidate the chemical structures of isolated compounds. Furthermore, all the isolated compounds were analyzed for 3-(4, 5-dimethylthiazol-2-yl)-5-diphenyltetrazolium bromide -based cytotoxicity studies on human colon cancer cell lines, HT-29 and HCT-15; among all the tested compounds, quercetin and odoratin-7-glucoside have shown a good cytotoxicity toward the selected cell lines.
\end{abstract}

\section{INTRODUCTION}

One of the most ancient sources of traditional medicines are raw materials extracted from the plants, and the heritage knowledge on preventive and curative medicines is based on the works of Atharva Veda, Charaka, and Sushruta. Globally, around 13,000 plant species are known to have been used as drugs, as they possess a wide variety of biologically active compounds that are essential to protect human health. Phytopharmaceuticals are one of the important parts of modern therapy for the alleviation of diseases of the cardiac and vascular system (Baharvand-Ahmadi et al., 2016), nervous system (Srivastava and Yadav, 2016), and

"Corresponding Author

Prasanna V. Habbu, Professor and Head, Postgraduate Department of Pharmacognosy and Phytochemistry, SET's College of Pharmacy, $S R$ Nagar, Dharwad 580 002,India.E-mail:prasherbs@yahoo.com immune system (Ford et al., 2016). Besides their therapeutic use, a large number of herbal drugs have been known for their prophylactic effect (Amirghofran et al., 2009; Kim et al., 2009). To develop new anticancer drugs in an estimated 7-10 years, we require a cost over $\$ 5,000,000$, and it is an inclusive cost for the initial collection of plant material; evaluation of crude fractions; purification, identification, and laboratory synthesis of the bioactive compounds; and preclinical and clinical studies. Many medicinal plants available in the market might contain chemical substances with potential mutagenic (Rattanachaikunsopon et al., 2009; Yao et al., 2007) as well as antitumor properties (Orfali et al., 2016; Wang et al., 2016). Such constituents act by destroying or blocking the DNA-damaging mutagens, thereby acting as protective agents by preventing cell mutation. Hence, herbs have a vital role in the prevention and treatment of cancer.

Bauhinia foveolata Dalzell (Leguminosae) is an endemic tree, native to Southwest India (the Western Ghats), naturally 
occurring only in Uttara Kannada district. Leaves are suborbicular, deeply cordate at base, glabrous above, and pubescent beneath, 15-17 nerved with minutely pitted beneath. Flowers are small, unisexual, in dense much-branched panicles, 5-lobed calyx tomentose, not much exerted and white-to-light cream corolla, alternatively long and short stamens, densely hairy ovary, linear-oblong pods, and red tomentose. The scientific name "foveolata" is derived from the minute pores covered on the underside of the leaves (foveoli). Recent literature reveals the antibacterial activity of $B$. foveolata Dalzell acetone fraction of bark against Streptococcus pyogenes (Gamit et al. 2018). No pharmacological/phytochemical reports are available for B. foveolata leaves until now. However, the phytochemical and pharmacological literatures are available on the other species of Bauhinia.

Bauhinia species contain a diversified group of secondary metabolites. The phytochemical constituents with varied chemical nature have been isolated from $B$. racemosa which chiefly include flavonoids (kaempferol and quercetin), coumarins (Prakash and Khosa, 1976), triterpenoids ( $\beta$-amyrin), steroids ( $\beta$-sitosterol) (ElHossary et al., 2000), stilbenes (resveratrol) (Aneyulu et al., 1984), and recently, pentacyclic phenolics (racemosolone from root bark) (Jain et al., 2013). A new linoleiyl-arabino-pyranoside from the stem bark of B. racemosa was isolated (Rahman and Akhtar, 2016). Bauhinia vahlii, another important species of Bauhinia, reported to contain compounds such as $\beta$-sitosterol (17.35\%), hexadecanoic acid $(10.15 \%)$, octadecanoic acid $(1.97 \%)$, oleic acid $(0.61 \%)$, cis-vaccenic acid $(2.43 \%), \alpha$-amyrin $(9.84 \%)$, methyl salicylate (2.39\%), and vitamin E (12.71\%). A new lactone, 7-epi-griffonilide (Almeida et al., 2017), was found in the leaves of Bauhinia pentandra. Lectins were isolated from the Bauhinia forficate and Bauhinia variegate fractions possessing anticancer (Lubkowski et al., 2017) and antibacterial (Klafke et al., 2016) activities, respectively. Attenuation of $\mathrm{H} / \mathrm{R}$-induced myocardial apoptosis strength by improving mitochondrial dysfunction through PI3K/Akt signaling pathway was observed for a flavone isolated from Bauhinia championii (Liao et al., 2016). Rutinoside and rhamnoside derivatives of kaempferol and quercetin, kaempferitin, were isolated from the leaves of $B$. uruguayensis and B. forficata subsp. Pruinosa (Santos et al., 2018).

A wide range of investigations on the cytotoxicity of flavonoids, such as apigenin, eriodictyol, 3-hydroxyflavone, kaempferol, luteolin, naringenin, taxifolin, quercetin, and rutin, toward cultured and tumor cells has been reported (Akbas et al., 2005; Matsuo et al., 2005). Although several bioactive constituents including flavonoids have been isolated from Bauhinia species, this is the first report on cytotoxic secondary metabolites from the leaves of B. foveolata Dalzell. The reported constituents were also isolated from several other medicinal plants, and some biological activities are reported (Dos et al., 2019; Rukshana, et al., 2017;).

\section{MATERIALS AND METHODS}

\section{Collection and authentication of plant material}

The leaves of B. foveolata Dalzell were collected from Dandeli reserve forest, Karnataka, India, and were authenticated by Dr. Harsha Hegde, Scientist, Regional Medical Research Centre, Belagavi, India. A voucher specimen has been kept in the herbarium of pharmacognosy department (SETCPD/Ph.cog/ herb/04/09/2016) for future reference.

\section{Extraction and preparation of crude fractions}

The authenticated leaves of $B$. foveolata Dalzell were dried and reduced to coarse powdered material. It was passed through 120-mesh sieves to remove any fine dust or powder, and the coarse powder was used for extraction. The powder was extracted exhaustively with $95 \%$ ethanol in a Soxhlet extractor. The total ethanolic extract was further fractionated with ethyl acetate and n-butanol by solvent-solvent extraction technique.

\section{Isolation of secondary metabolites from ethyl acetate fraction}

About $15 \mathrm{~g}$ of the ethyl acetate fraction was mixed with $15 \mathrm{~g}$ of silica gel (60-120) mesh, using ethyl acetate as the solvent. The drug adsorbed silica was then loaded on top of the glass column which was previously packed with $230 \mathrm{~g}$ of silica gel (60-120 mesh) using petroleum ether by the wet packing method. The column was eluted first with $100 \%$ petroleum ether followed by petroleum ether:ethyl acetate graded mixtures (99:1, 98:2, $95: 5,90: 10,80: 20,70: 30,60: 40,50: 50,40: 60,30: 70,20: 80$, and $10: 90$ ), then with $100 \%$ ethyl acetate followed by EtOAc:MeOH graded mixtures (99:1, 98:2, 95:5, 90:10, 80:20, 70:30, 60:40, $50: 50,40: 60,30: 70,20: 80$, and 10:90), and then with $100 \%$ $\mathrm{MeOH}$. Each test tube contained $10 \mathrm{ml}$ of elutes which were concentrated and monitored by thin-layer chromatography (TLC) (Silica Gel GF 254, visualization under UV 254 and $366 \mathrm{~nm}$ ). Elutions were carried out with graded mixtures of EtOAc:MeOH (80:20 and 70:30), resulted in a single spot on TLC with EtOAc:methanol (7.5:2.5) as mobile phase. After removing the solvent, a brownish residue was obtained $(1.5 \mathrm{~g})$, with $\mathrm{R}_{\mathrm{f}}$ value of 0.52 at water:MeOH:BuOH (1:3:6) as the solvent system. These portions were further subjected to flash chromatography.

\section{Flash chromatography}

About $1.5 \mathrm{~g}$ of the EtOAc:MeOH (80:20 and 70:30) fraction was adsorbed on $4 \mathrm{~g}$ of flash grade silica (230-400 mesh) using motor and pestle. Prepacked silica column RediSep (12 g) was used. The sample was loaded and placed in flash chromatography instrument. All the parameters were set and monitored using CombiFlash software. The column was eluted with gradient elution system using EtOAc: $\mathrm{MeOH}$ and $\mathrm{MeOH}$, with concentration ranging from $0 \%$ to $50 \%$. The eluents were monitored on TLC and visualized under UV 254 and $366 \mathrm{~nm}$. Detection was performed using ferric chloride as spraying reagent. Identical elutes were collected, combined (TLC monitored), concentrated, and kept aside. A prominent peak was obtained with $10 \%$ of methanol in ethyl acetate. Elutions which were collected separately in test tubes and TLC studies were performed using EtOAc:MeOH (8:2) as a mobile phase with the $\mathrm{R}_{\mathrm{f}}$ of 0.52 . After concentration of the solvent, a dark brown residue was obtained, which was designated as DN 1 (70 mg).

\section{Isolation of secondary metabolites from butanol fraction}

Nearly $30 \mathrm{~g}$ of butanol fraction was adsorbed with $30 \mathrm{~g}$ of silica (60-120 mesh). The sample was loaded on a column 1 packed with $840 \mathrm{~g}$ of silica (60-120 mesh) by wet packing method. The column was first eluted with $100 \%$ petroleum ether followed 
by petroleum ether:ethyl acetate graded mixtures $(99: 1,98: 2$, $95: 5,90: 10,80: 20,70: 30,60: 40,50: 50,40: 60,30: 70,20: 80$, and $10: 90)$, then with $100 \%$ ethyl acetate followed by EtOAc:MeOH graded mixtures $(99: 1,98: 2,95: 5,90: 10,80: 20,70: 30,60: 40$, $50: 50,40: 60,30: 70,20: 80$, and 10:90), and then finally with $100 \% \mathrm{MeOH}$. All the elutions were monitored on TLC (Silica gel GF 254; visualization by UV $254 \mathrm{~nm}$ and $366 \mathrm{~nm}$ ) and $\mathrm{FeCl} 3$ as spraying reagent. Eluates obtained with 80:20, 70:30, and 60:40 of EtOAc: $\mathrm{MeOH}(8: 2)$ resulted in a single prominent spot on TLC nearly having the same $\mathrm{R}_{\mathrm{f}}$ value. These three fractions were pooled, combined together, and evaporated to obtain $15 \mathrm{~g}$ which was further subjected to rechromatography.

$15 \mathrm{~g}$ of the above-obtained fraction was adsorbed with $15 \mathrm{~g}$ of flash grade silica (230-400 mesh). The sample was loaded on a column 2 packed with $200 \mathrm{~g}$ of silica (60-120 mesh) by wet packing method. The column was first eluted with $100 \%$ petroleum ether followed by petroleum ether:ethyl acetate graded mixtures $(99: 1,98: 2,95: 5,90: 10,80: 20,70: 30,60: 40,50: 50,40: 60,30: 70$, $20: 80$, and 10:90), then with $100 \%$ ethyl acetate followed by EtOAc:MeOH graded mixture (99:1, 98:2, 95:5, 90:10, 80:20, $70: 30,60: 40,50: 50,40: 60,30: 70,20: 80$, and 10:90), and then finally with $100 \% \mathrm{MeOH}$. All the elutions were monitored by TLC (Silica gel GF 254; visualization by UV $254 \mathrm{~nm}$ and $366 \mathrm{~nm}$ ) and detected using $\mathrm{FeCl}_{3}$ as spraying reagent.

Eluates obtained with 99:1 and 95:5 of 100\% EtOAc: $\mathrm{MeOH}(9: 1)$ resulted in a single prominent spot on TLC. These elutions were pooled and concentrated to obtain $5 \mathrm{~g}$ which was further subjected to rechromatography.

$5 \mathrm{~g}$ of the above-obtained fraction was adsorbed with $5 \mathrm{~g}$ of flash grade silica (230-400 mesh). The sample was loaded on a column 3 packed with $30 \mathrm{~g}$ of flash grade silica (230-400 mesh) by wet packing method. The elutions were carried out by $100 \%$ $\mathrm{CHCl}_{3}$ followed by $\mathrm{CHCl}_{3}$ :ethyl acetate graded mixtures (50:50 and $25: 75$ ), then by $100 \%$ ethyl acetate followed by EtOAc:MeOH graded mixture $(99.5: 0.5,99: 1,98.5: 1.5,98: 2,97.5: 2.5,97: 3,95: 5$, $90: 10,80: 20,70: 30,60: 40,50: 50,40: 60,30: 70,20: 80$, and 10:90), and then finally with $100 \% \mathrm{MeOH}$. All the elutions were monitored by TLC. Eluates obtained with $100 \%$ EtOAc resulted in a single spot on TLC for flavonoids (EtOAc:FA:GA: $\mathrm{H}_{2} \mathrm{O},--100: 11: 11: 26$ ). After removing the solvent, yellowish brown-colored compound was obtained (75 mg), which was designated as DN 2. Eluates obtained with EtOAc:MeOH (95:5) resulted in three spots on TLC for flavonoids (EtOAc:FA:GA: $\left.\mathrm{H}_{2} \mathrm{O}, 100: 11: 11: 26\right)$. After removing the solvent, yellow-colored compound was obtained (400 mg), which was designated as DN 3 which was subjected to rechromatography. Eluates obtained with EtOAc:MeOH (90:10 and 80:20) resulted in two spots with nearly the same $\mathrm{R}_{\mathrm{f}}$ values on TLC for flavonoids (EtOAc:FA:GA: $\mathrm{H}_{2} \mathrm{O}, 100: 11: 11: 26$ ).

\section{Rechromatography of DN 3}

Four hundred milligrams of the fraction was adsorbed on $500 \mathrm{mg}$ of flash grade silica (230-400 mesh) using motor and pestle. The sample was loaded on a prepacked column 4 with $30 \mathrm{~g}$ of flash grade silica by wet packing method. The elutions were carried out at a very slow flow rate, i.e., 10 drops per min with 100\% EtOAc, then with EtOAc:MeOH graded mixture (99.9:0.1, 99.5:0.5, 99:1, 98:2, 97:3 till 90:10), and then finally by $100 \%$ $\mathrm{MeOH}$. Elutions in the test tubes were collected and subjected for TLC. Test tube $(0-8)$ showed no spots. Fractions eluted with EtOAc: $\mathrm{MeOH}(99.5: 0.5)$ in the test tubes (9-23) showed prominent single spot with the $R_{\mathrm{f}}$ of 0.72 . After removing the solvent, yellow-colored compound was obtained $(90 \mathrm{mg})$, which was designated as BF-1(1). Eluates obtained with EtOAc:MeOH (99:1) in test tubes (24-41) showed one single spot with the Rf of 0.51 . Later removing the solvent, pale yellow-colored compound was obtained $(85 \mathrm{mg}$ ), which was designated as BF-2 (2). The test tube (42-52) eluted with EtOAc:MeOH (98:2) resulted in one single spot with the $\mathrm{R}_{\mathrm{f}}$ of 0.25 . After concentrating the eluents, whitish yellow-colored compound was obtained $(72 \mathrm{mg})$, which was designated as BF-3(3). The solvent system used for TLC was EtOAc:FA:GAA: $\mathrm{H}_{2} \mathrm{O}$ (100:11:11:26), and the detection was done using $\mathrm{FeCl}_{3}$ reagent.

\section{Conditions used for liquid chromatography-mass spectrometry (LC-MS) analysis}

The mobile phase consisted of water containing $0.05 \%$ phosphoric acid (A) and acetonitrile (B) at a flow rate of 0.8 $\mathrm{ml}$ minute $^{-1}$ using the following gradients: $0.1-23$ minutes, $10 \%-40 \%$ of solvent $\mathrm{B}$ in $\mathrm{A}$, and $23.01-40$ minutes, $10 \%$ solvent $\mathrm{B}$ and $90 \%$ solvent $\mathrm{A}$. The detection was done on a Diode-Array Detection (DAD) detector set at $340 \mathrm{~nm}$. The mobile phase was prepared daily, filtered through a $0.45-\mathrm{mm}$ membrane filter (Millipore), and sonicated before use. The LC/Electrospray ionization (ESI)-MS was conducted in positive-ion mode and operated according to the defined conditions: nitrogen gas temperature $-320^{\circ} \mathrm{C}$, drying gas flow rate -71 minute $^{-1}$, capillary voltage $-4,000 \mathrm{~V}$, and nebulizing pressure -27 psi. Mass spectra were recorded using the full scan mode in the range of 200-800 Daltons.

Mass spectra (MS) were recorded using a JEOL GCMATE II GC-Mass spectrometer and Shimadzu QP 20105 GC-Mass spectrometer. Analytical TLC was performed on precoated TLC sheets of silica gel 60 F254 (Merck, Darmstadt, Germany) visualized by long- and short-wavelength UV lamps. Chromatographic purifications were performed on Merck aluminum oxide (70-230 mesh) and Merck silica gel (70-230 mesh).

\section{IN VITRO CYTOTOXICITY STUDY}

\section{Chemicals}

Dulbecco's Modified Eagle's Medium (DMEM), fetal bovine serum (FBS), 3-(4, 5-dimethylthiazol-2-yl)-5diphenyltetrazolium bromide (MTT), phosphate-buffered saline (PBS), trypsin, dimethyl sulfoxide (DMSO), and propanol were obtained from Merck Ltd., Mumbai, India. Ethylenediaminetetraacetic acid, glucose, and antibiotics were purchased from HiMedia Laboratories Ltd., Mumbai, India.

\section{Cell cultures}

HT-29 and HCT-15 (Human colon cancer) cells were procured from the National Centre for Cell Science, Pune, India. The stock cells of all cell lines were cultured in DMEM supplemented with $10 \%$ inactivated FBS, penicillin $(100 \mathrm{IU} / \mathrm{ml})$, and streptomycin $(100 \mu \mathrm{g} / \mathrm{ml})$ in a humidified atmosphere of $5 \% \mathrm{CO}_{2}$ at $37^{\circ} \mathrm{C}$ until confluent. The cells were dissociated with 
TPVG solution $(0.2 \%$ trypsin, $0.02 \%$ EDTA, and $0.05 \%$ glucose in PBS). The stock cultures were grown in 25-ml flat bottles, and all the experiments were carried out in either 96-well microtiter plates.

\section{Cell proliferation assessment-MTT assay}

The monolayer of cell culture was trypsinized and the cell count was adjusted to $3.0 \times 10^{4}$ cells $/ \mathrm{ml}$ using DMEM medium containing $10 \%$ FBS. $0.1 \mathrm{ml}$ of the diluted cell suspension was added to each well of the 96-well microtiter plate. After 24 hours, the supernatant of monolayer formed was removed and washed with medium, and $100 \mu \mathrm{l}$ of different concentrations of phytoconstituents were added on to the partial monolayer in microtiter plates. Microscopic examination of the samples was carried out, and the observations were noted every 24 hours interval after incubating the plates at $37^{\circ} \mathrm{C}$ for 3 days in a $5 \% \mathrm{CO}_{2}$ atmosphere. After 72 hours, $50 \mu 1$ of MTT in PBS was added to each well after discarding the drug solutions. The plates were gently shaken and incubated for 3 hours at $37^{\circ} \mathrm{C}$ in $5 \% \mathrm{CO}_{2}$ atmosphere. The supernatant was removed and $100 \mu \mathrm{l}$ of propanol was added, and the plates were gently shaken to solubilize the formed formazan. The absorbance was measured using a microplate reader (ELISA reader, BioTek) at a wavelength of $570 \mathrm{~nm}$. The growth inhibition percentage was calculated, and the concentration of test compound required to inhibit $50 \%$ cell growth by $\mathrm{CTC}_{50}$ values is generated from the dose-response curves for each cell line (Alley et al., 1988; Langner et al., 2019).

\section{RESULTS AND DISCUSSION}

The structure of isolated compounds depicted in (Fig. 1). 13-Docosenamide (DN1) was obtained as amorphous dark brown powder, mp $76^{\circ} \mathrm{C}-78^{\circ} \mathrm{C}$; $R_{\mathrm{f}}: 0.52$ (EtOAc: $\left.\mathrm{MeOH}, 8: 2\right)$ ) IR (KBr): 2,922 (NH), 2,850 (CH), 1,701 $(\mathrm{C}=\mathrm{O}) \mathrm{cm}^{-1} ;{ }^{1} \mathrm{H}$ Nuclear Magnetic Resonance (NMR) (400 MHz, DMSO, $\delta, \mathrm{ppm}): 0.83$ (3H, d, $J=$ $\left.8 \mathrm{~Hz},-\mathrm{CH}_{3}\right), 0.93-1.33\left(30 \mathrm{H}, \mathrm{s}, \mathrm{C}_{3}, \mathrm{C}_{4}, \mathrm{C}_{5}, \mathrm{C}_{6}, \mathrm{C}_{7}, \mathrm{C}_{8}, \mathrm{C}_{9}, \mathrm{C}_{10}, \mathrm{C}_{11}\right.$, $\left.\mathrm{C}_{16}, \mathrm{C}_{17}, \mathrm{C}_{18}, \mathrm{C}_{19}, \mathrm{C}_{20}, \mathrm{C}_{21}-\mathrm{H}\right), 1.46-2.33\left(6 \mathrm{H}, \mathrm{m}, \mathrm{C}_{2}, \mathrm{C}_{12}, \mathrm{C}_{15}-\mathrm{H}\right)$, $5.29\left(1 \mathrm{H}, \mathrm{d}, J=12 \mathrm{~Hz}, \mathrm{C}_{13}-\mathrm{H}\right), 5.48\left(1 \mathrm{H}, \mathrm{d}, J=8 \mathrm{~Hz}, \mathrm{C}_{14}-\mathrm{H}\right), 6.21$ $\left(2 \mathrm{H}, \mathrm{s},-\mathrm{NH}_{2}\right) ;{ }^{13} \mathrm{C}$ NMR $(75 \mathrm{MHz}, \mathrm{DMSO}, \delta, \mathrm{ppm}): 17.45\left(\mathrm{C}_{22}\right)$, $28.32\left(\mathrm{C}_{3}, \mathrm{C}_{21}\right), 29.00\left(\mathrm{C}_{4}, \mathrm{C}_{5}, \mathrm{C}_{6}, \mathrm{C}_{7}, \mathrm{C}_{8}, \mathrm{C}_{9}, \mathrm{C}_{10}, \mathrm{C}_{11}, \mathrm{C}_{16}, \mathrm{C}_{17}, \mathrm{C}_{18}\right.$, $\left.\mathrm{C}_{19}\right), 32.20\left(\mathrm{C}_{12}, \mathrm{C}_{15}, \mathrm{C}_{20}\right), 38.99\left(\mathrm{C}_{2}\right), 134.15\left(\mathrm{C}_{13}, \mathrm{C}_{14}\right), 177.69$ $(\mathrm{C}=\mathrm{O})$; Mass spectra EI-MS: $\mathrm{m} / \mathrm{z}(\%)=337.2\left[\mathrm{M}^{+}\right](100)$.

Quercetin(1) was obtained as amorphous yellow powder, mp $180^{\circ} \mathrm{C}-182^{\circ} \mathrm{C} ; R_{\mathrm{f}}: 0.72$ (EtOAc: $\left.\mathrm{MeOH}, 99.5: 0.5\right)$; $\mathrm{IR}(\mathrm{KBr})$ : $3253(\mathrm{OH}), 2,926(\mathrm{CH}), 1,784(\mathrm{C}=\mathrm{O}), 1,656(\mathrm{C}-\mathrm{O}) \mathrm{cm}^{-1},{ }_{1} \mathrm{H}$ NMR (400 MHz, DMSO, $\delta$, ppm):5.21 (1H, s, C $-\mathrm{H}), 5.27\left(1 \mathrm{H}, \mathrm{s}, \mathrm{C}_{8}-\mathrm{H}\right)$, $6.84\left(3 \mathrm{H}, \mathrm{d}, \mathrm{C}_{2}^{\prime}, \mathrm{C}_{5}^{\prime}, \mathrm{C}_{6}, \mathrm{H}\right), 9.58(2 \mathrm{H}, \mathrm{s}, \mathrm{OH}), 10.83(2 \mathrm{H}, \mathrm{s}, \mathrm{OH})$, $12.66(1 \mathrm{H}, \mathrm{s}, \mathrm{OH}),{ }^{13} \mathrm{C}$ NMR $(75 \mathrm{MHz}, \mathrm{DMSO}, \delta, \mathrm{ppm}): 98.66$ $\left(\mathrm{C}_{6}, \mathrm{C}_{8}\right), 104.04\left(\mathrm{C}_{5}\right), 115.62\left(\mathrm{C}_{2}, \mathrm{C}_{5}\right), 120.71\left(\mathrm{C}_{6}\right), 121.08\left(\mathrm{C}_{1}{ }^{\prime}\right)$, $134.17\left(\mathrm{C}_{2}\right), 145.16\left(\mathrm{C}_{3}^{\prime}, \mathrm{C}_{4}^{\prime}\right), 148.39\left(\mathrm{C}_{3}{ }^{\prime}\right), 157.26\left(\mathrm{C}_{3}\right), 161.26$ $\left(\mathrm{C}_{9}, \mathrm{C}_{10}\right), 164.17\left(\mathrm{C}_{7}\right), 177.70\left(\mathrm{C}_{4}\right)$; Mass spectra GC-MS: m/z (\%) $=303.06\left[\mathrm{M}^{+}+1\right]$.

Isorhamnetin (2) was obtained as pale yellow amorphous powder, mp $184^{\circ} \mathrm{C}-186^{\circ} \mathrm{C}$; $R_{\mathrm{f}}$ : 0.51 (EtOAc: $\mathrm{MeOH}, 99: 1$ ); IR(KBr): 3,253, 2,926, 1,784, 1,656, 1,454, 1,355 cm ${ }^{-1} ;{ }^{1} \mathrm{H}$ NMR (400 MHz, DMSO, $\delta, \mathrm{ppm}): 3.73\left(3 \mathrm{H}, \mathrm{s}, \mathrm{CH}_{3}\right), 5.21\left(1 \mathrm{H}, \mathrm{s}, \mathrm{C}_{6}-\mathrm{H}\right)$, $5.27\left(1 \mathrm{H}, \mathrm{s}, \mathrm{C}_{8}-\mathrm{H}\right), 6.84\left(3 \mathrm{H}, \mathrm{d}, \mathrm{C}_{2}^{\prime}, \mathrm{C}_{5}^{\prime}, \mathrm{C}_{6}^{\prime}-\mathrm{H}\right), 9.58(1 \mathrm{H}, \mathrm{s}, \mathrm{OH})$,
$10.83(2 \mathrm{H}, \mathrm{s}, \mathrm{OH}), 12.66(1 \mathrm{H}, \mathrm{s}, \mathrm{OH}) ;{ }^{13} \mathrm{C}$ NMR $(75 \mathrm{MHz}, \mathrm{DMSO}$, $\delta$, ppm): $93.59\left(\mathrm{C}_{7}^{\prime}\right), 98.66\left(\mathrm{C}_{6}, \mathrm{C}_{8}\right), 104.04\left(\mathrm{C}_{5}\right), 115.62\left(\mathrm{C}_{2}^{\prime}, \mathrm{C}_{5}{ }^{\prime}\right)$, $120.71\left(\mathrm{C}_{6}{ }^{\prime}\right), 121.08\left(\mathrm{C}_{1}{ }^{\prime}\right), 134.17\left(\mathrm{C}_{2}\right), 145.16\left(\mathrm{C}_{4}{ }^{\prime}\right), 148.39\left(\mathrm{C}_{3}{ }^{\prime}\right)$, $157.26\left(\mathrm{C}_{3}\right), 161.26\left(\mathrm{C}_{9}, \mathrm{C}_{10}\right), 164.17\left(\mathrm{C}_{7}\right), 177.70\left(\mathrm{C}_{4}\right)$; Mass spectra GC-MS: $\mathrm{m} / \mathrm{z}(\%)=317.07\left[\mathrm{M}^{+}+1\right](100)$.

Odoratin-7-glucoside (3) was obtained as pale yellow amorphous powder, $\mathrm{mp} 184^{\circ} \mathrm{C}-186^{\circ} \mathrm{C} ; R_{\mathrm{f}}: 0.25$ (EtOAc: $\mathrm{MeOH}$, 98:2); IR(KBr): 3,482 (OH), 1,771 (C=O), 1,626 (C-O) $\mathrm{cm}^{-1} ;{ }^{1} \mathrm{H}$ NMR (400 MHz, DMSO, $\delta$, ppm): $3.45\left(1 \mathrm{H}, \mathrm{s}, \mathrm{C}_{2} \mathrm{OH}\right), 3.57$ $\left(1 \mathrm{H}, \mathrm{s}, \mathrm{C}_{2} \mathrm{OH}\right), 3.64\left(2 \mathrm{H}, \mathrm{s}, \mathrm{C}_{6}{ }^{\prime \prime}, \mathrm{C}_{5}{ }^{\prime \prime}-\mathrm{H}\right), 3.73\left(1 \mathrm{H}, \mathrm{s}, \mathrm{C}_{4}{ }^{\prime \prime}-\mathrm{H}\right), 3.76$ $\left(3 \mathrm{H}, \mathrm{s},-\mathrm{OC}_{3}\right), 3.85\left(3 \mathrm{H}, \mathrm{s},-\mathrm{OCH}_{3}\right), 3.99\left(1 \mathrm{H}, \mathrm{s}, \mathrm{CH}_{2}-\mathrm{OH}\right), 4.19$ $\left(1 \mathrm{H}, \mathrm{s}, \mathrm{C}_{3}{ }^{\prime \prime}-\mathrm{H}\right), 4.73\left(2 \mathrm{H}, \mathrm{s},-\mathrm{OH}\right.$ at $\left.\mathrm{C}_{3}{ }^{\prime \prime}, \mathrm{C}_{4}{ }^{\prime \prime}-\mathrm{H}\right), 4.88(1 \mathrm{H}, \mathrm{s},-\mathrm{OH}$ at $\left.\mathrm{C}_{5}{ }^{\prime}\right), 5.59\left(1 \mathrm{H}, \mathrm{s}, \mathrm{C}_{2}{ }^{\prime \prime}-\mathrm{H}\right), 6.48-6.64\left(1 \mathrm{H}, \mathrm{m}, \mathrm{C}_{8}-\mathrm{H}\right), 6.85-6.94(2 \mathrm{H}$, m, $\left.\mathrm{C}_{2}{ }^{\prime}, \mathrm{C}_{5}{ }_{5}-\mathrm{H}\right), 7.04\left(1 \mathrm{H}, \mathrm{s}, \mathrm{C}_{6}{ }^{\prime}-\mathrm{H}\right), 7.26-7.39\left(1 \mathrm{H}, \mathrm{s}, \mathrm{C}_{5}-\mathrm{H}\right), 8.06$ $\left(1 \mathrm{H}, \mathrm{d}, J=8 \mathrm{MHz}, \mathrm{C}_{2}-\mathrm{H}\right), 9.72\left(1 \mathrm{H}, \mathrm{s},-\mathrm{OH}\right.$ at $\left.\mathrm{C}_{3}{ }^{\prime}-\mathrm{H}\right) ;{ }^{13} \mathrm{C}$ NMR $(75$ $\mathrm{MHz}, \mathrm{DMSO}, \delta, \mathrm{ppm}): 63.04\left(-\mathrm{OCH}_{3}\right), 69.88\left(-\underline{\mathrm{CH}}_{2} \mathrm{OH}\right), 70.02$ $\left(\mathrm{C}_{5}{ }_{5}\right), 74.06\left(\mathrm{C}_{3}{ }^{\prime \prime}\right), 76.46\left(\mathrm{C}_{4}{ }^{\prime \prime}\right), 77.48\left(\mathrm{C}_{6}{ }^{\prime \prime}\right), 100.86\left(\mathrm{C}_{8}\right), 104.05\left(\mathrm{C}_{5}\right.$, $\left.\mathrm{C}_{2}^{\prime \prime}\right), 115.18\left(\mathrm{C}_{5}^{\prime}\right), 115.75\left(\mathrm{C}_{2}^{\prime}, \mathrm{C}_{9}\right), 121.56\left(\mathrm{C}_{1}, \mathrm{C}_{1}^{\prime}, \mathrm{C}_{6}^{\prime}\right), 144.76$ $\left(\mathrm{C}_{6}\right), 148.41\left(\mathrm{C}_{3}^{\prime}, \mathrm{C}_{4}^{\prime}\right), 156.41\left(\mathrm{C}_{2}, \mathrm{C}_{7}, \mathrm{C}_{10}\right), 177.44(\mathrm{C}=\mathrm{O})$; Mass spectra (GC-MS) m/z (\%): $475.33\left[\mathrm{M}^{+}-1\right]$.

\section{Cytotoxicity study}

All the isolated constituents were subjected for cytotoxicity studies on human colon cancer cell lines, i.e., HT-29 and HCT-15. Among the compounds tested, quercetin and odoratin-7-glucoside have shown a good cytotoxicity with $\mathrm{IC}_{50}$ of $75.33 \pm 10.01,95.00 \pm 5.56$ towards HT-29 cancer cell line and $105.06 \pm 6.52,102.45 \pm 10.22$ towards HCT-15 cancer cell line. The results are shown in Table 1 . The study also supports the presence of these constituents in many medicinal plants with therapeutic potential as reported by many authors, namely, essential oil obtained from Zingiber collinsii Mood and Theilade found to contain 13-Docosenamide (2.7\%) (Chau et al. 2014). GC-MS analysis of the ethanol extract of leaf of Pergularia daemia (Forssk.) Chiov. found to contain 13-docosenamide (Rukshana et al., 2017). It is reported to possess antibacterial, antifungal (Dos Reis CM et al., 2019), and cytotoxic (Sharma et al., 2018) activities. Odoratin was isolated from the aerial parts of Taverniera aegyptiaca Bioss. (Hassan et al., 2019), Derris eriocarpa (Wang et al., 2015), and Chromolaena odorata (Zhang et al., 2012). It exhibited PPAR $\gamma$ transactivation, estrogenic (Umehara et al., 2008), antigiardial (Khan et al., 2000), and cytotoxic (against the human epidermoid carcinoma of the nasopharynx and the lymphocytic leukemia) activities (Hoffmann et al., 1978). Hence, these secondary metabolites may be ideal candidates for the development of anticancer phytopharmaceutical formulation.

Table 1. In vitro cytotoxicity study of phytoconstituents on HT-29 and HCT-15 cell lines $(n=3)$

\begin{tabular}{lcc}
\hline \multirow{2}{*}{ Phytoconstituents } & \multicolumn{2}{c}{ CTC 50\% \pm SEM $(\boldsymbol{\mu g} / \mathbf{m l})$} \\
\cline { 2 - 3 } & HT-29 & HCT-15 \\
\hline 13-Docosenamide & $747.33 \pm 10.26$ & $572.33 \pm 12.21$ \\
Isorhamnetin & $115 \pm 18.02$ & $211 \pm 08.02$ \\
Quercetin & $75.33 \pm 10.01$ & $105.06 \pm 6.52$ \\
Odoratin-7-glucoside & $95 \pm 5.56$ & $102.45 \pm 10.22$ \\
\hline
\end{tabular}




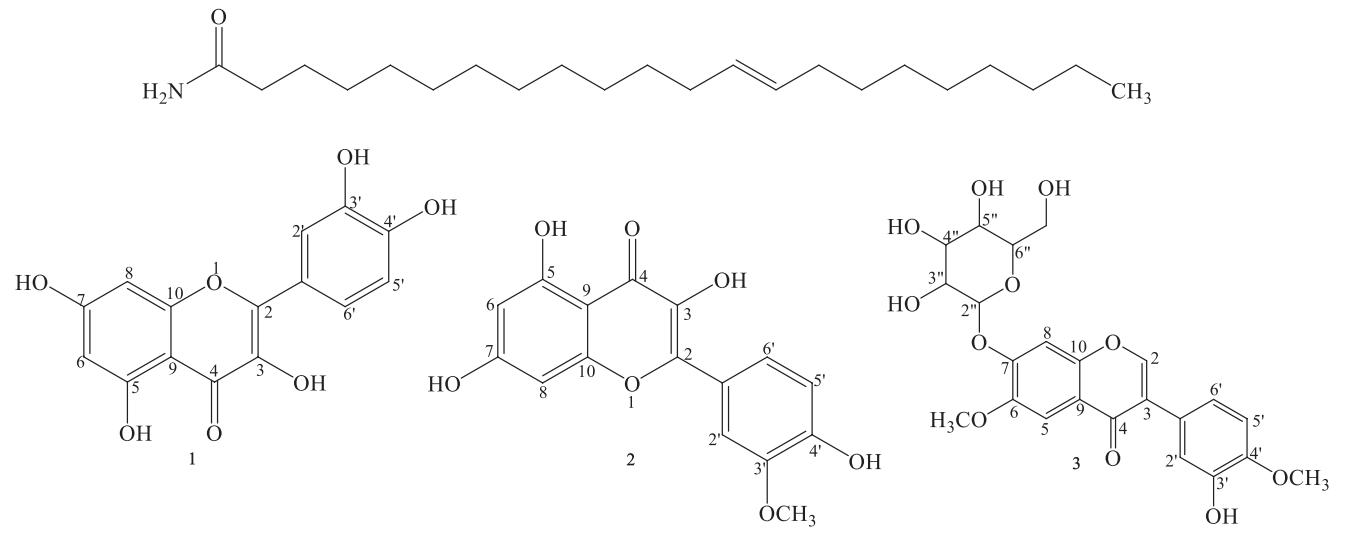

Figure 1. Structures of isolated phytoconstituents: 13-Docosenamide [DN1], (1) Quercetin; (2) Isorhamnetin; (3) Odoratin-7-Glucoside.

\section{CONCLUSION}

The research work successfully explores the cytotoxic principles from the leaves of $B$. foveolata Dalzell, an endemic tree of the Western Ghats, India. It is evident that these metabolites belong to the class polyphenolic compounds. Among the compounds studied against HT-29 and HCT-15 colon cancer cell lines of human, odoratin-7-glucoside and quercetin have proved to be highly cytotoxic by inducing apoptosis of cancer cells. Further research on the in vivo anticancer activity of potential fractions and to study the chemical diversity of this plant for other pharmacological activities is under progress in the laboratory.

\section{ACKNOWLEDGMENTS}

The authors are thankful to Dr. Harsha Hegde, Scientist, Regional Medical Research Centre, Belagavi, for identification and authentication of plant material. The authors are also thankful to Principal, SET's college of Pharmacy and President, Soniya Education Trust, Dharwad, for providing necessary laboratory facilities. Sophisticated analytical instrumentation facility center (SAIF) and central instrumentation laboratory (CIL), Punjab University, are highly acknowledged for providing the spectral data of isolated compounds.

\section{CONFLICT OF INTEREST}

Authors declare that they have no conflicts of interest.

\section{REFERENCES}

Akbas SH, Timur M, Ozben T. The effect of quercetin on topotecan cytotoxicity in MCF-7 and MDA-MB 231 human breast cancer cells. J Surg Res, 2005; 125(1):49-55.

Alley MC, Scudiero DA, Monks A, Hursey ML, Czerwinski MJ, Fine DL, Abbott BJ, Mayo JG, Shoemaker RH, Boyd ${ }^{\circ} \mathrm{MR}$. Feasibility of drug screening with panels of human tumor cell lines using a microculture tetrazolium assay. Cancer Res, 1988; 48(3):589-601.

Almeida MCS, Souza LGS, Ferreira DA, Pinto FCL, Oliveira DR, Santiago GMP, Monte FJQ, Braz-Filho R, Lemos TLG. 7-epigriffonilide, a new lactone from Bauhinia pentandra: complete ${ }^{1} \mathrm{H}$ and ${ }^{13} \mathrm{C}$ chemical shift assignments. An Acad Bras Cienc, 2017; 89(1):65-71.

Amirghofran Z, Bahmani M, Azadmehr A, Javidnia K, Miri R. Immunomodulatory activities of various medicinal plant extracts: effects on human lymphocytes apoptosis. Immunol Invest, 2009; 38(2):181-92.

Aneyulu ASR, Reddy AVR, Reddy DSK, Ward RS, Adhikesavalu D, Cameron TS. A new dibenzo $(2,3-6,7)$ oxepin derivative from Bauhinia racemosa. Tetrahedron, 1984; 40:4245-52.
Baharvand-Ahmadi B, Bahmani M, Tajeddini P, Rafieian-Kopaei M, Naghdi N. An ethnobotanical study of medicinal plants administered for the treatment of hypertension. J Renal Inj Prev, 2016; 9:123-8.

Chau LTM, Tran DT, Le VD, Nguyen TMT, Isiaka AO. Constituents of some essential oil bearing plants from Vietnam. Am J Plant Sci, 2014; 5:760-5.

Dos RCM, da Rosa BV, da Rosa GP, do Carmo G, Morandini LMB, Ugalde GA, Kuhn KR, Morel AF, Jahn SL, Kuhn RC. Antifungal and antibacterial activity of extracts produced from Diaportheschini. J Biotechnol, 2019; 294:30-7.

El-Hossary GA, Selim MA, Sayed AE, Khaleel AE. Study of the flavonoid content of Bassiamuricata \& Bauhinia racemosa. Bull Fac Pharm Cairo Univ, 2000; 38:93-7.

Gamit SB, Sapra P, Vasava MS, Solanki HA, Patel H, Rajani D. Antimicrobial and antimalarial activities of some selected ethno-medicinal plants used by tribal communities of Tapi District, Gujarat, India. Int Res J Pharm, 2018; 9(10):151-6.

Hassan AR, Amer KF, El-Toumy SA, Nielsen J, Christensen SB. A new flavonol glycoside and other flavonoids from the aerial parts of Taverniera aegyptiaca. Nat Prod Res, 2019; 33(8):1135-9

Hoffmann JJ, Jolad SD, Torrance SJ, Luzbetak DJ, Wiedhopf RM, Cole JR. Odoratin and paucin: cytotoxic sesquiterpene lactones from Baileyapauciradiata (Compositae). J Pharm Sci, 1978; 67(11):1633-4.

Jain R, Yadav N, Bhagch T, Jain SC. A new pentacyclic phenol $\&$ other constituents from the root bark of Bauhinia racemosa Lamk. Nat Prod Res, 2013; 27(20):1870-6.

Khan IA, Avery MA, Burandt CL, Goins DK, Mikell JR, Nash TE, Azadegan A, Walker LA. Antigiardial activity of isoflavones from Dalbergia frutescens bark. J Nat Prod, 2000; 63(10):1414-6.

Kim YS, Park HJ, Kim TK, Moon DE, Lee HJ. The effects of Ginkgobiloba extract EGB 761 on mechanical and cold allodynia in a rat model of neuropathic pain. AnesthAnalg, 2009; 108(6):1958-63.

Klafke GB, Moreira GM, Pereira JL, Oliveira PD, Conceição FR, Lund RG, Grassmann AA, Dellagostin OA, da Silva Pinto L. Lectin-I from Bauhinia variegata (BVL-I) expressed by Pichia pastoris inhibits initial adhesion of oral bacteria invitro. Int J Biol Macromol, 2016;93:913-8.

Langner E, Lemieszek MK, Rzeski W. Lycopene, sulforaphane, quercetin, and curcumin applied together show improved antiproliferative potential in colon cancer cells invitro. J Food Biochem, 2001;9:1-12.

Liao P, Sun G, Zhang C, Wang M, Sun Y, Zhou Y, Sun X, Jian J. Bauhinia championii flavone attenuates hypoxia-reoxygenation induced apoptosis in $\mathrm{H} 9 \mathrm{c} 2$ cardiomyocytes by improving mitochondrial dysfunction. Molecules, 2016; 21(11):pii: E1469.

Lubkowski J, Durbin SV, Silva MC, Farnsworth D, Gildersleeve JC, Oliva ML, Wlodawer A. Structural analysis and unique molecular recognition properties of a Bauhinia forficata lectin that inhibits cancer cell growth. FEBS J, 2017; 284(3):429-50. 
Matsuo M, Sasaki N, Saga K, Kaneko T. Cytotoxicity of flavonoids toward cultured normal human cells. Biol Pharm Bull, 2005; 28(2):253-9.

Orfali GC, Duarte AC, Bonadio V, Martinez NP, Branco de Araújo MEM, Priviero FBM, Carvalho PO, Priolli DG. Review of anticancer mechanisms of isoquercitin. World J Clin Oncol, 2016; 7(2):189-99.

Prakash A, Khosa RL. Chemical studies on Bauhinia racemosa. Curr Sci, 1976; 45:705.

Rahman MA, Akhtar JA. New linoleiylarabinopyranoside from the bark of Bauhinia racemosa Lam and a new flavonoidal glycoside from the leaves of Cordiadichotoma Linn. Nat Prod Res, 2016; 30(20):2265-73.

Rattanachaikunsopon P, Phumkhachorn P. Prophylactic effect of Andrographis paniculata extracts against Streptococcus agalactiae infection in Nile tilapia (Oreochromis niloticus). J Biosci Bioeng, 2009; 107(5):579-82.

Rukshana MS, Doss A, Pushpa RTP. Phytochemical screening and GC-MS analysis of leaf extract of Pergulariadaemia (Forssk) Chiov, Asian J Plant Sci Res, 2017; 7(1):9-15.

Santos M, Fortunato RH, Spotorno VG. Analysis of flavonoid glycosides with potential medicinal properties on Bauhinia uruguayensis and Bauhinia forficate subspecies pruinosa. Nat Prod Res, 2019; 33(17):2574-8

Sharma A, Singh S, Tewari R, Bhatt VP, Sharma J, Maurya IK. Phytochemical analysis and mode of action against Candida glabrata of Paeonia emodi extracts. J Mycol Med, 2018; 28(3):443-51.

Srivastava P, Yadav RS. Efficacy of natural compounds in neurodegenerative disorders. Adv Neurobiol, 2016; 12:107-23.

Umehara K, Nemoto K, Kimijima K, Matsushita A, Terada E, Monthakantirat O, De-Eknamkul W, Miyase T, Warashina T, Degawa
M, Noguchi H. Estrogenic constituents of the heartwood of Dalbergia parviflora. Phytochemistry, 2008; 69(2):546-52.

Wang Y, Wang J, Wang H, Ye W. Novel taxane derivatives from Taxus wallichiana with high anticancer potency on tumor cells, Chem Bio Drug Des, 2016; 88(4):556-61.

Wang LX, Wu HG, Zhang H, Lou HY, Liang GY, Jiang WW, Yang ZC, Pan WD. Studies on flavonoids from Derris eriocarpa. Zhongguo Zhong Yao Za Zhi, 2015; 40(15):3009-12.

Yao P, Song F, Li K, Zhou S, Liu S, Sun X, Nussler AK, Liu L. Ginkgobiloba extract prevents ethanol induced dyslipidemia. Am J Chin Med, 2007; 35(4):643-52.

Zhang ML, Irwin D, Li XN, Sauriol F, Shi XW, Wang YF, Huo $\mathrm{CH}, \mathrm{Li}$ LG, Gu YC, Shi QW. PPAR $\gamma$ agonist from Chromolaena odorata. J Nat Prod, 2012; 75(12):2076-81.

\section{How to cite this article:}

Habbu PV, Miskin N, Kulkarni VH, Bhat P, Joshi A, Bhandarkar A, Kulkarni S, Dixit SR, Vaijanathappa J. Isolation, characterization, and cytotoxic studies of secondary metabolites from the leaves of Bauhinia foveolata Dalzell: An endemic tree from the Western Ghats, India. J Appl Pharm Sci, 2020; 10(03):135-148. 


\section{SUPPLEMENTARY MATERIAL}

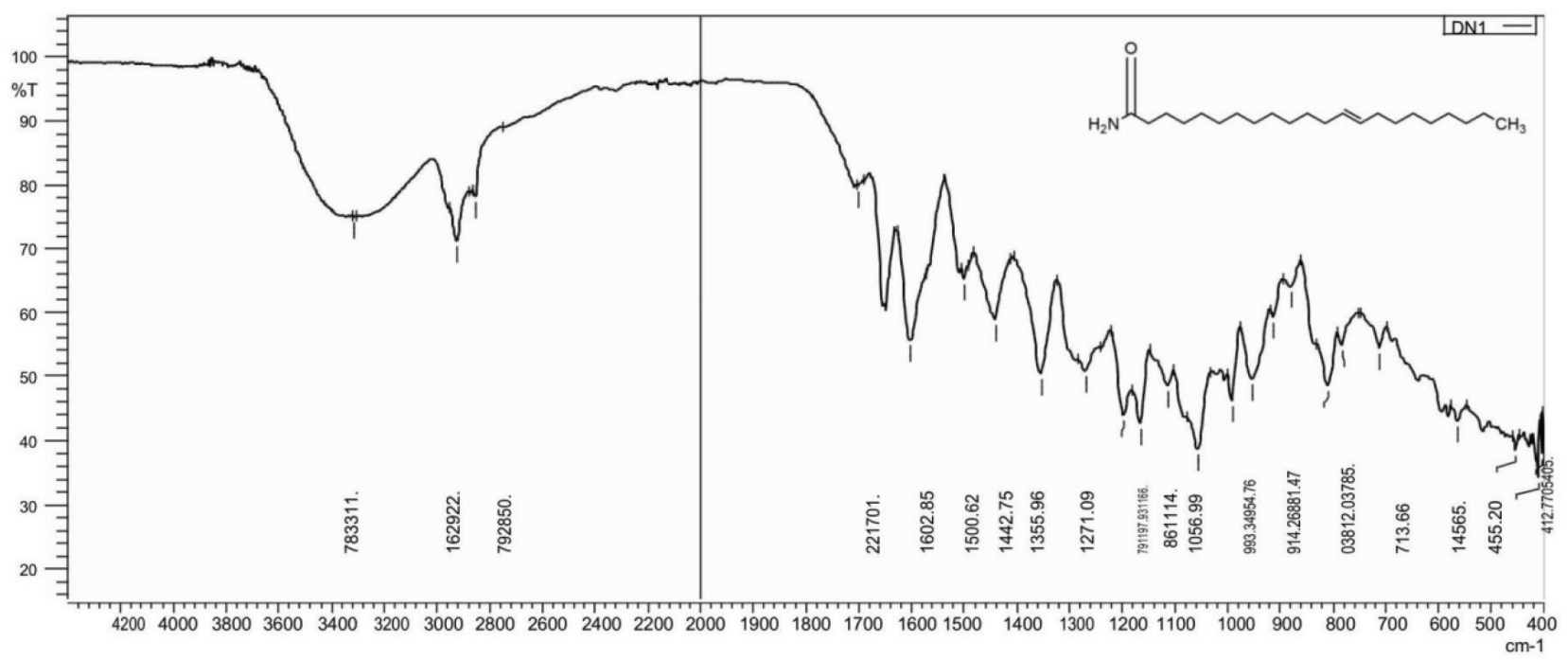

IR Spectrum of DN 1

DN1

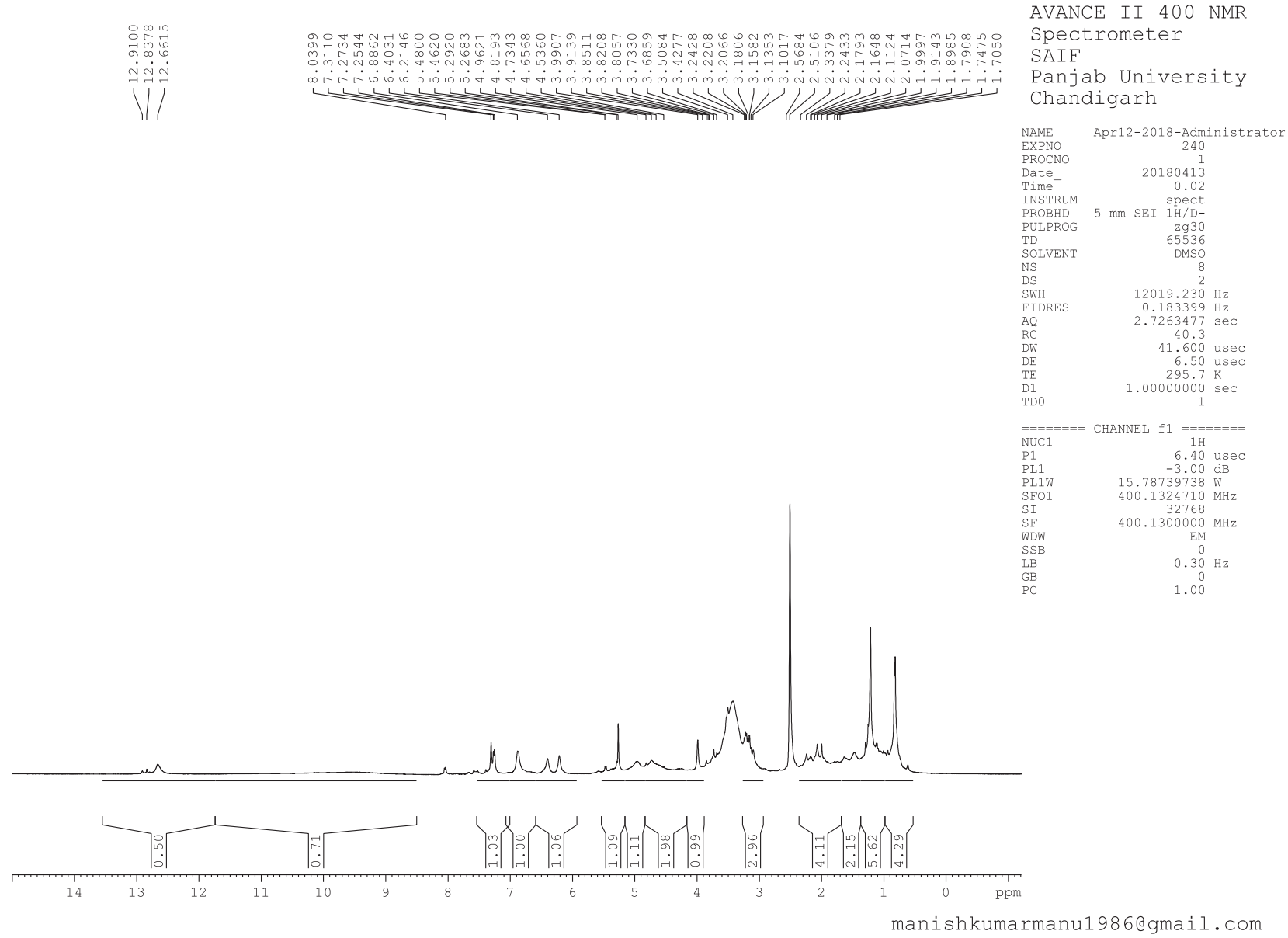

${ }^{1}$ H NMR Spectrum of DN 1 
DN1

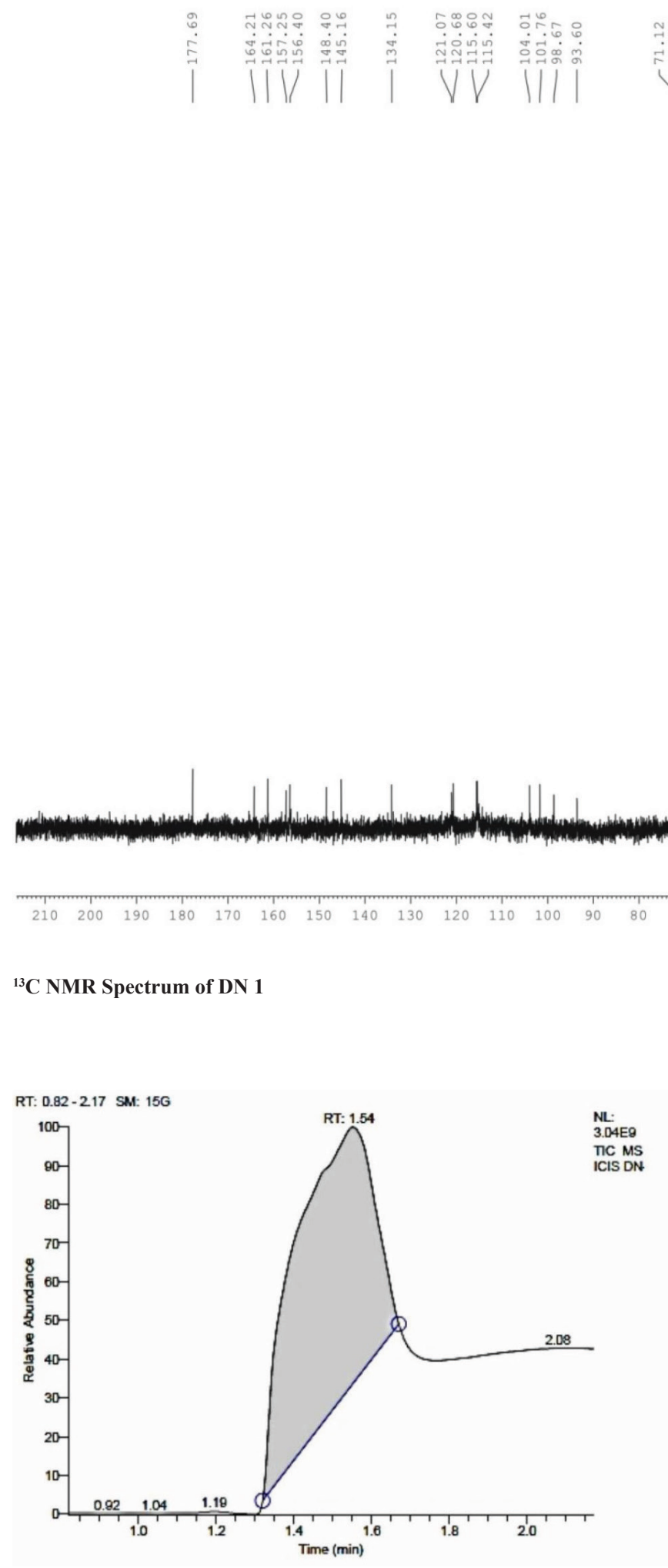

BRUKER

AVANCE II 400 NMR

Spectrometer

SAIF

Panjab University

Chandigarh

NAME
EXPNO

$\begin{array}{lr}\text { EXPNO } & 241 \\ \text { PROCNO } & 1\end{array}$

$\begin{array}{ll}\text { PROCNO } & 20180413 \\ \text { Date- } & 0.30\end{array}$

$\begin{array}{lr}\text { Time }^{-} & 0.30 \\ \text { INSTRUM } & \text { spect }\end{array}$

PROBHD $5 \mathrm{~mm}$ SEI $1 \mathrm{H} / \mathrm{D}-$

PULPROG

SOLVENT

NS

SWH $\quad 29761.904 \mathrm{~Hz}$

$\begin{array}{lr}\text { FIDRES } & 0.454131 \mathrm{~Hz} \\ \text { AQ } & 1.1010548 \mathrm{sec}\end{array}$

RG $\quad 181 \mathrm{sec}$

$\begin{array}{lr}\text { DW } & 16.800 \text { usec } \\ \text { DE } & 6.50 \text { usec } \\ \text { TEE } & 295.9 \mathrm{~K}\end{array}$

$\begin{array}{ll}\text { D1 } & 2.00000000 \mathrm{sec} \\ \text { D11 } & 0.03000000 \mathrm{sec}\end{array}$

$======0$ CHANNEL $\mathrm{f} 1=====\overline{=}$

$\begin{array}{lr}\text { NUC1 } & 13 \mathrm{C} \\ \text { P1 } & 14.90 \text { usec } \\ \text { PL1 } & -3.00 \mathrm{~dB}\end{array}$

PL1W $\quad 60.64365387 \mathrm{~W}$

$100.6228298 \mathrm{MHz}$

=m=m=m= CHANNEL $f 2=m$
waltz16

NU
PC
PI
PL
PL
PI
PL
PL
SE
SI
SE
WD
SS
LB
GB
PC

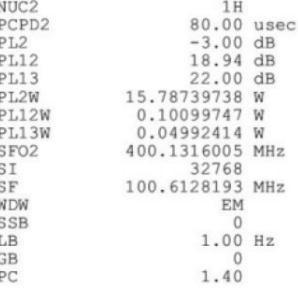




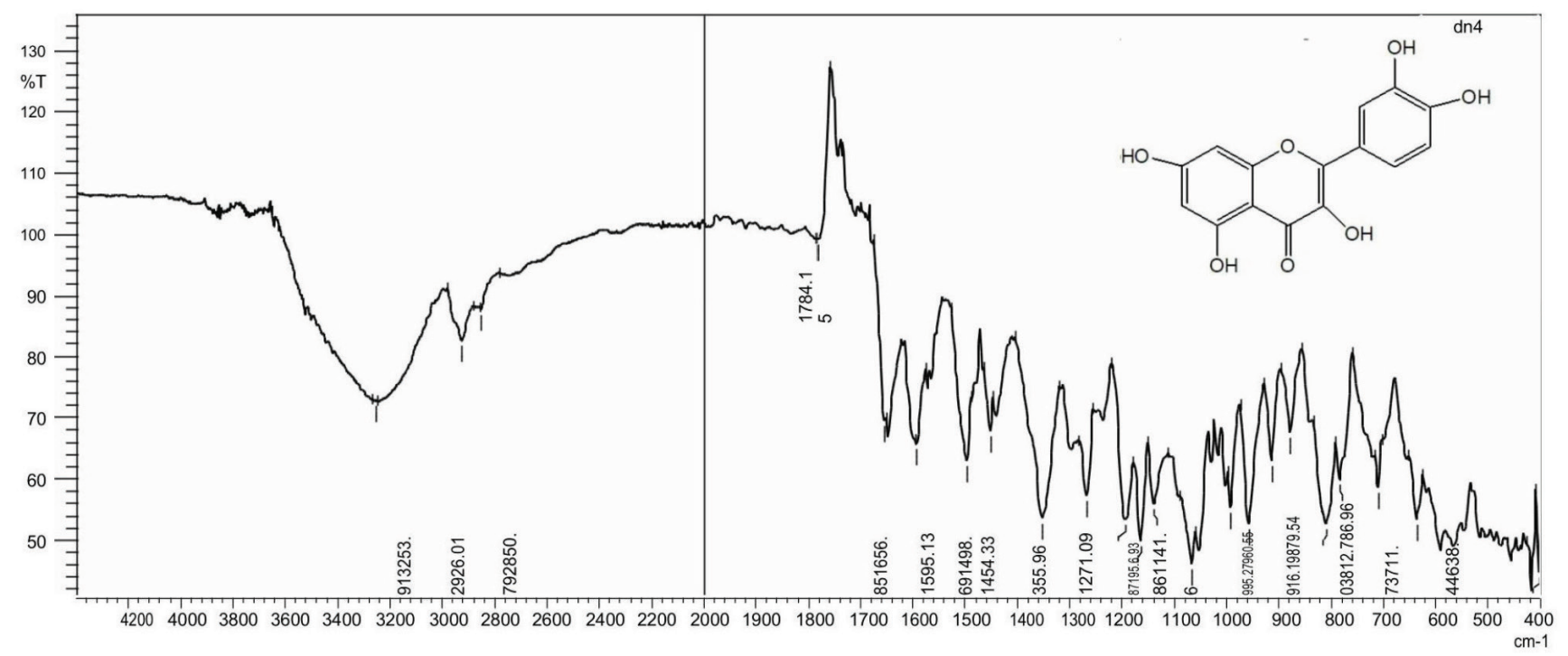

IR Spectrum of BF 1

Bf1

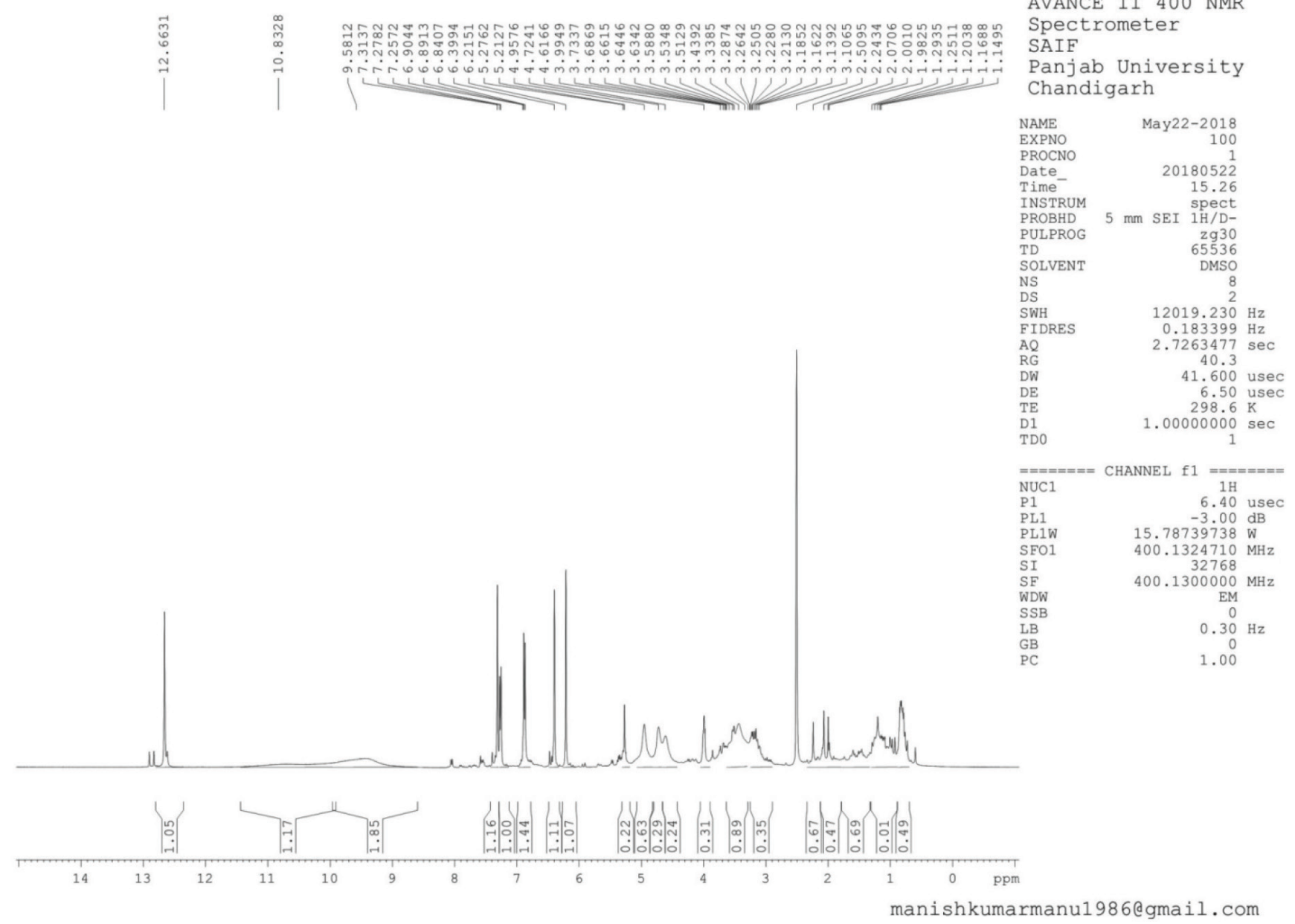

${ }^{1} \mathrm{H}$ NMR Spectrum of BF 1 


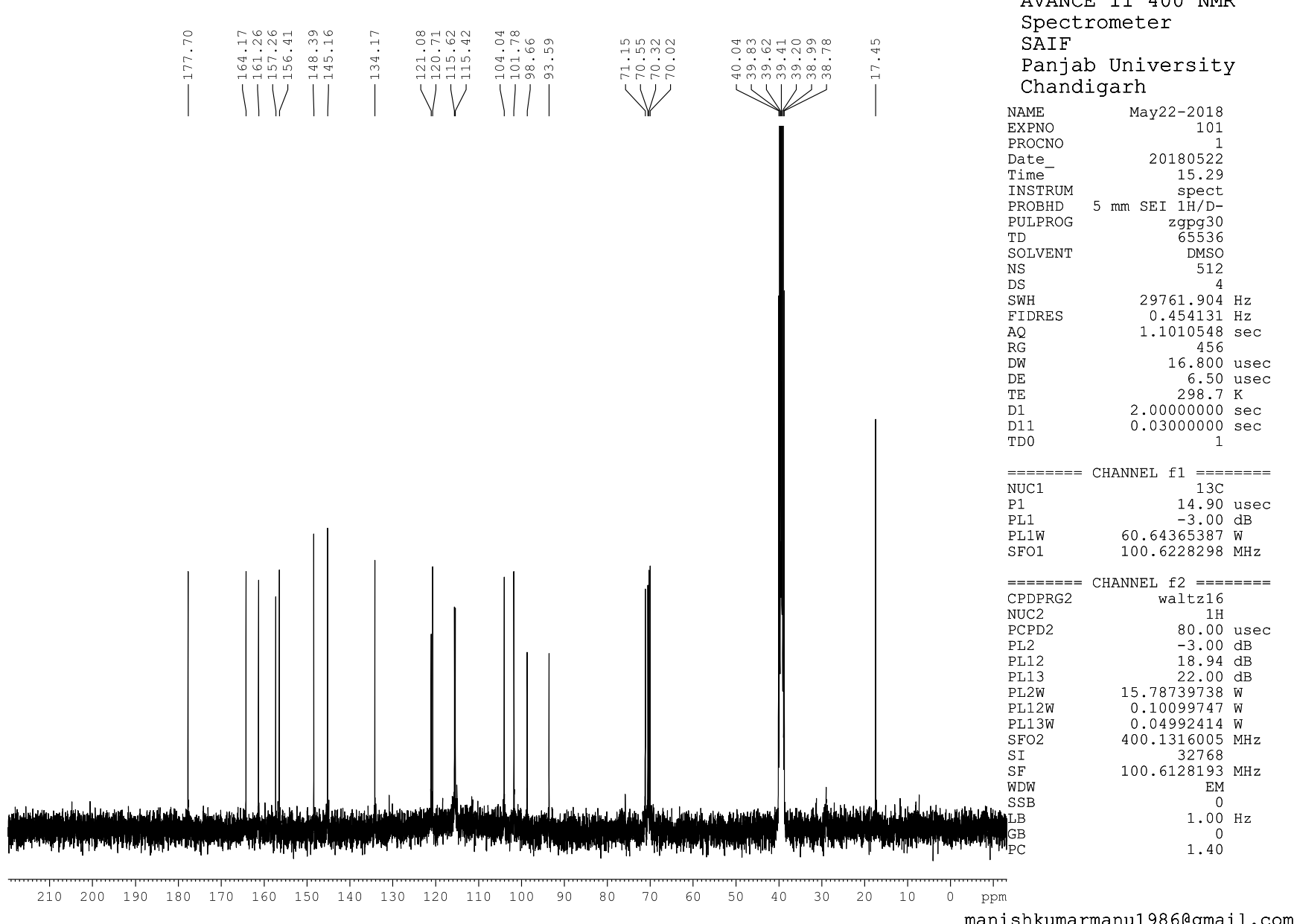

${ }^{13} \mathrm{C}$ NMR Spectrum of BF1

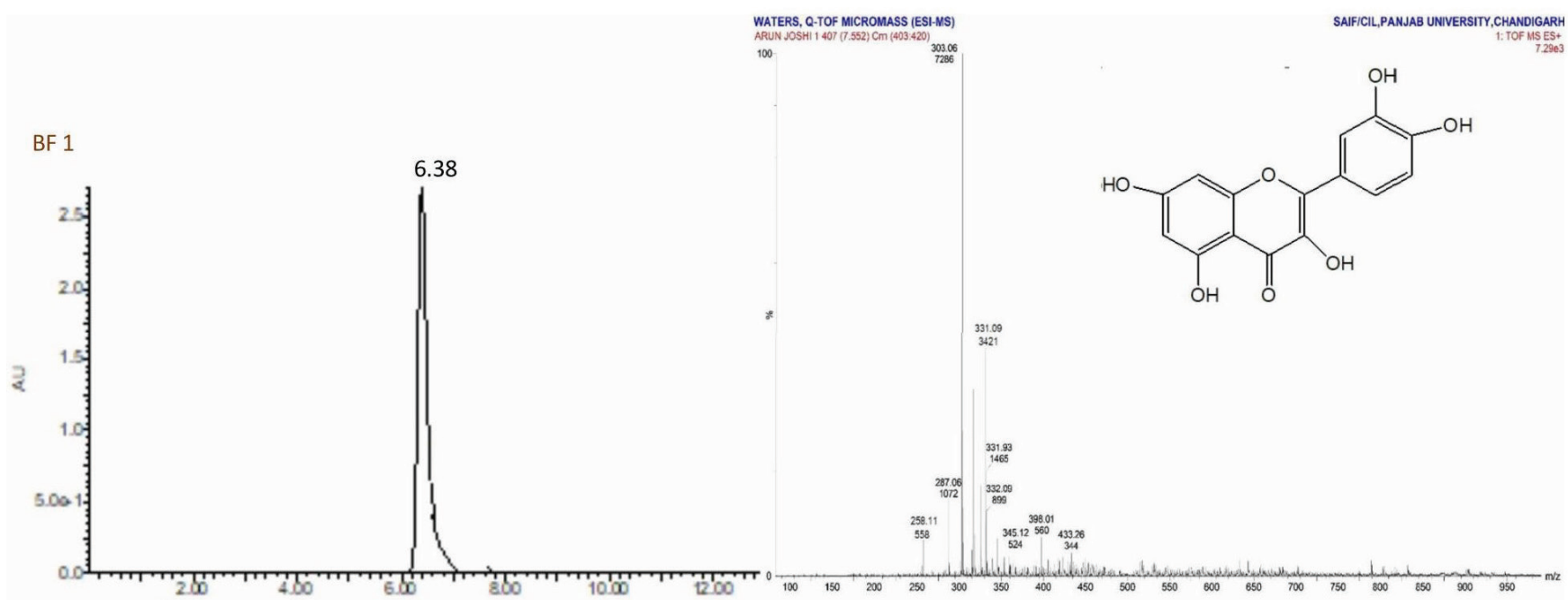

LC-MS Spectrum of BF 1 


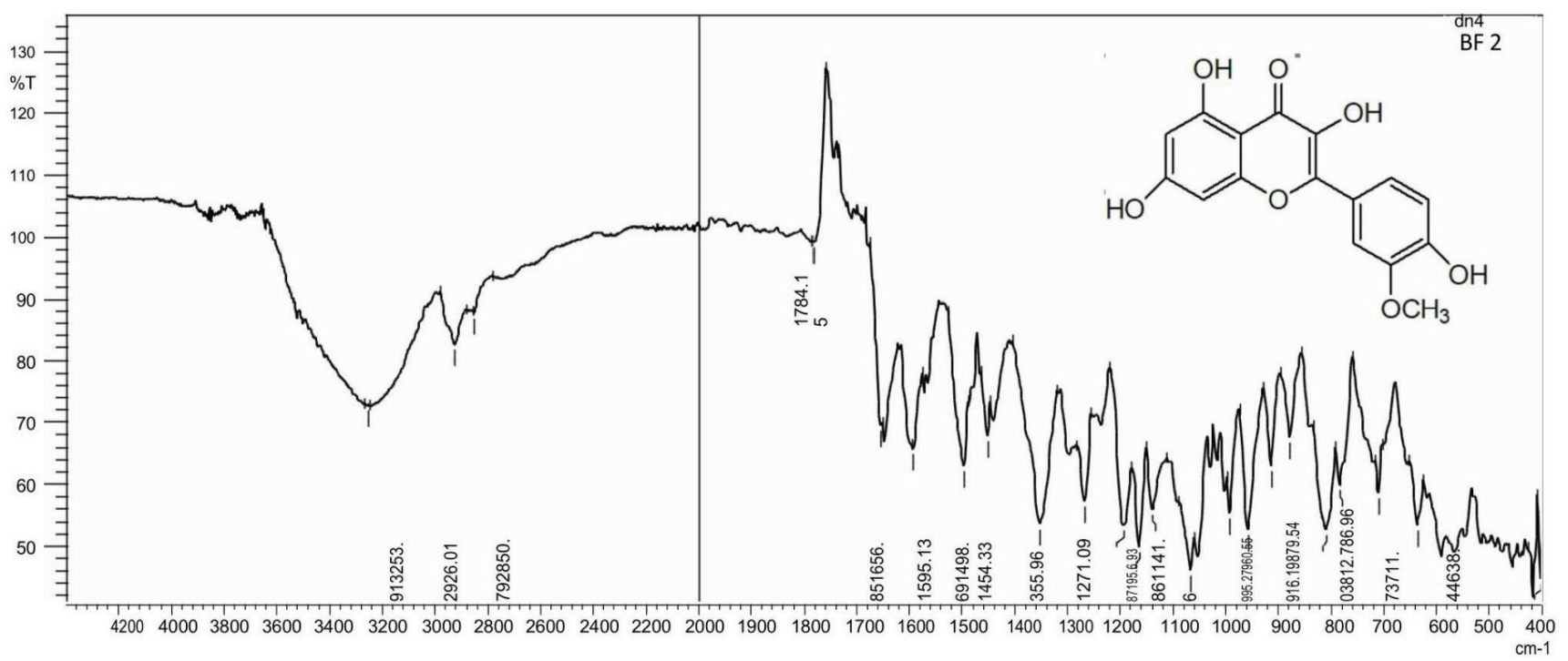

\section{IR Spectrum of BF 2}

Bf2

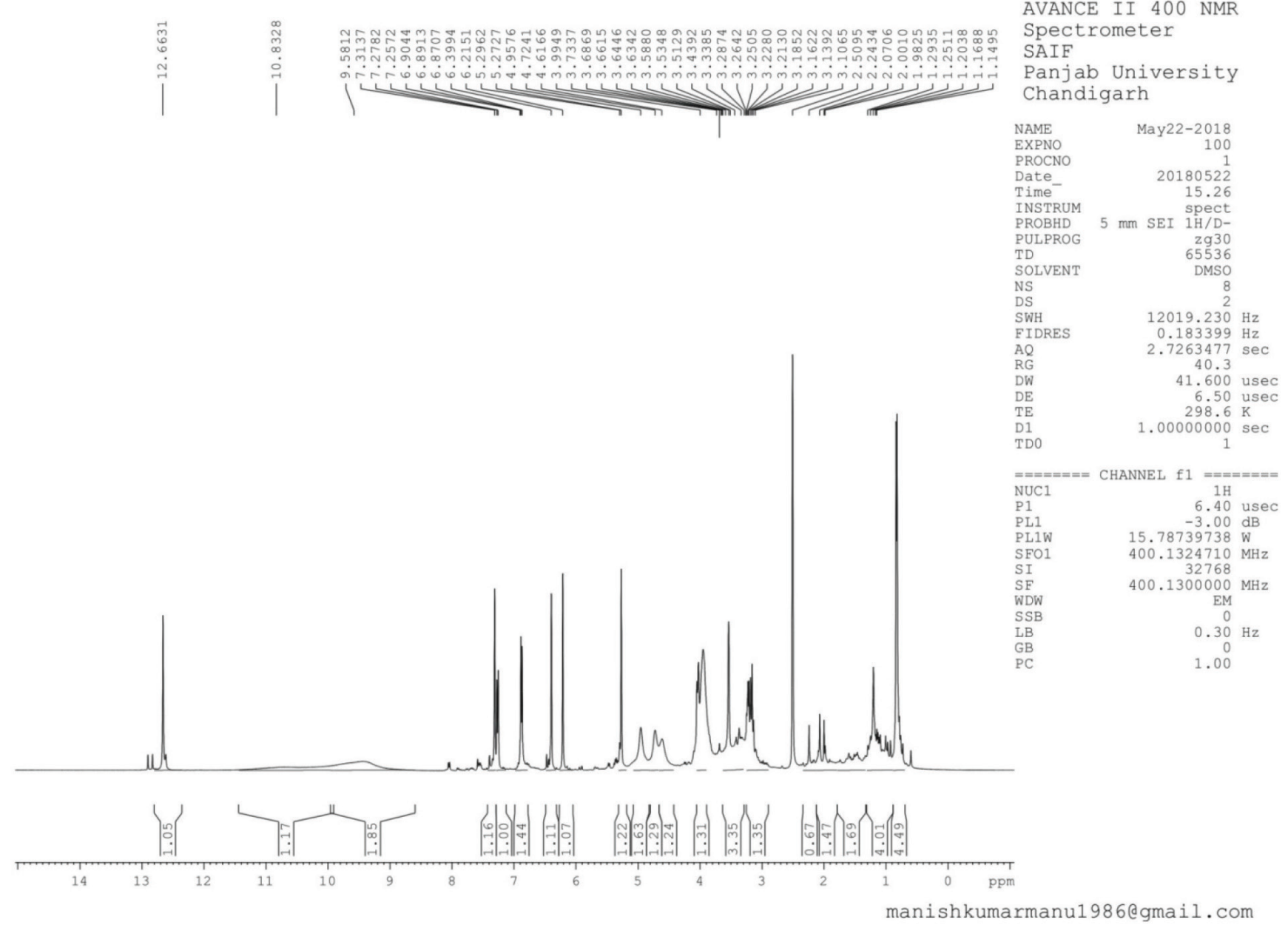

${ }^{1} \mathrm{H}$ NMR Spectrum of BF2 


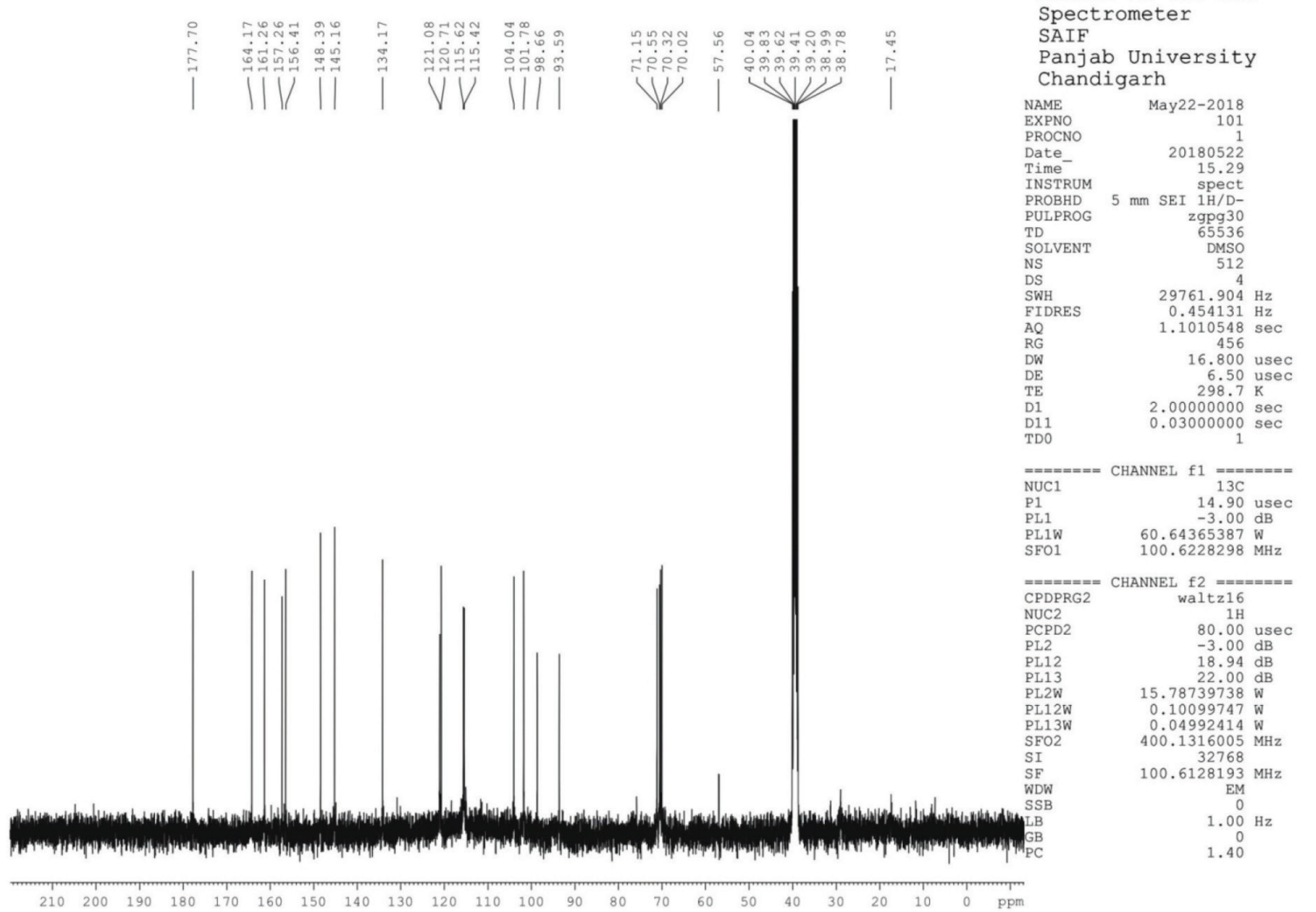

${ }^{13} \mathrm{C}$ NMR Spectrum of BF2

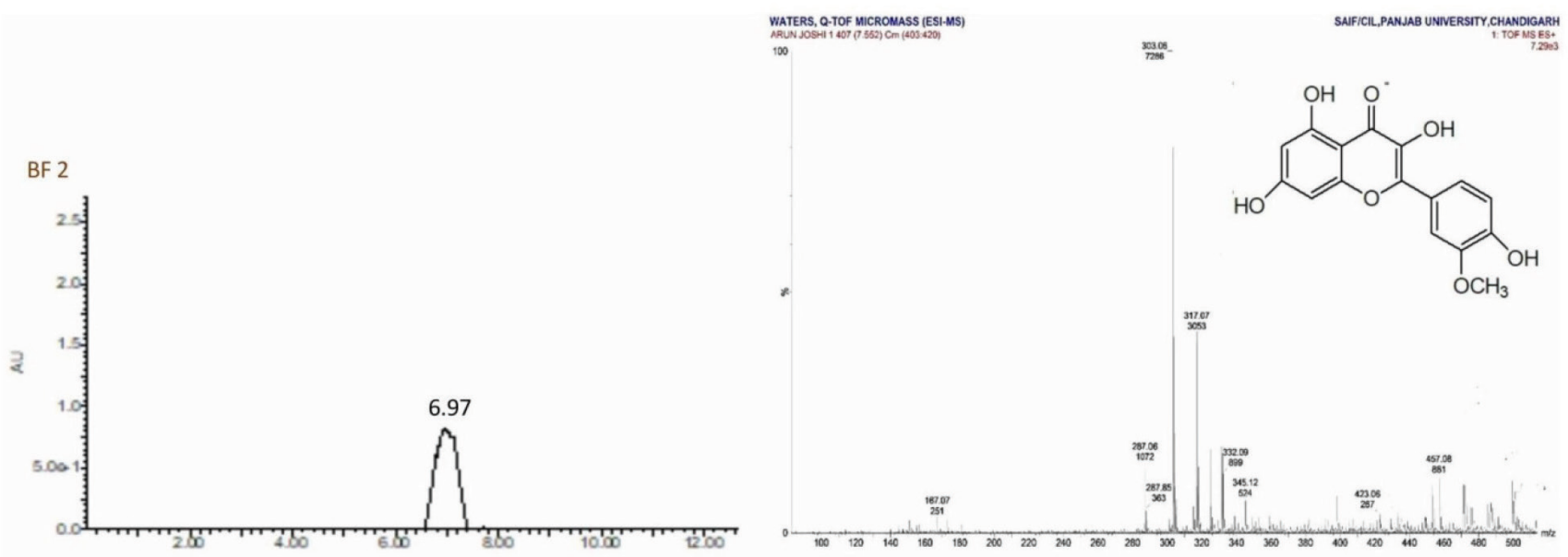

LC-MS Spectrum of BF 2 


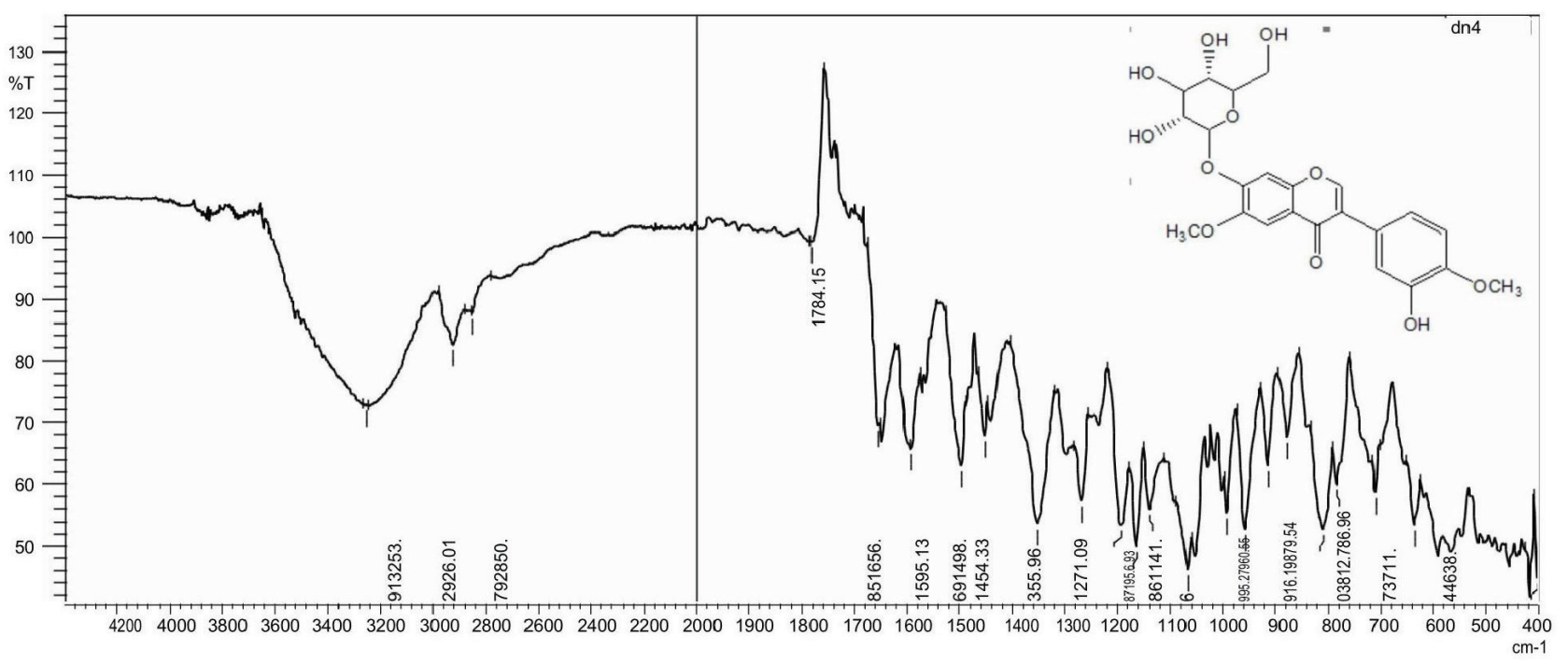

IR Spectrum of BF 3

DN5

BRUKER

AVANCE I I 400 NMR

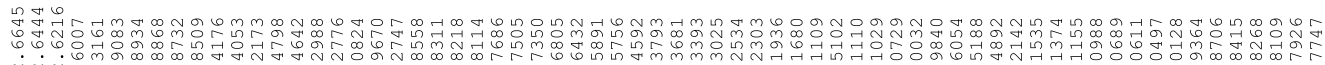

羿

Spectrometer

Panjab University

Chandigarh

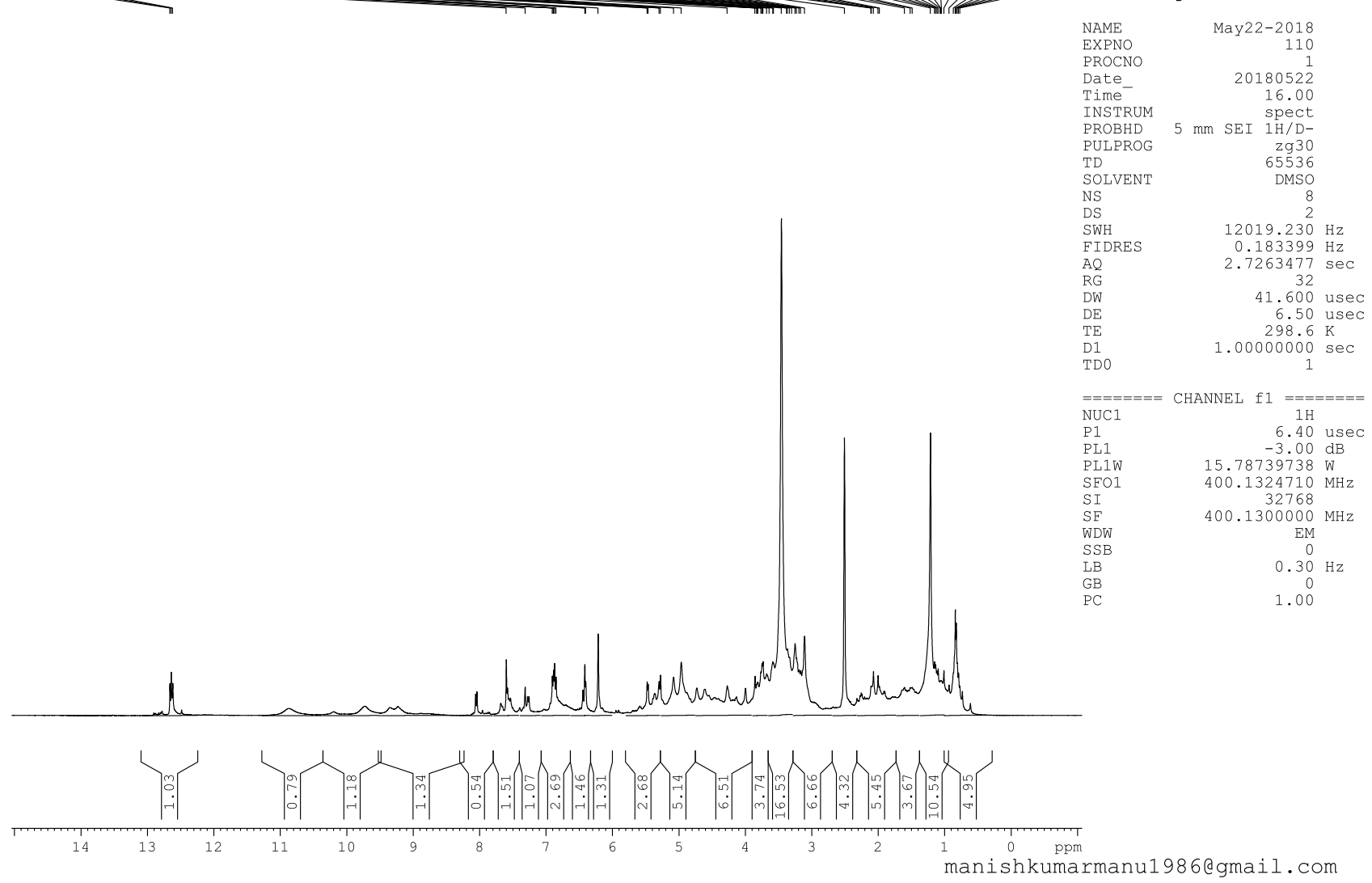

${ }^{1} \mathrm{H}$ NMR Spectrum of BF3 
DN5
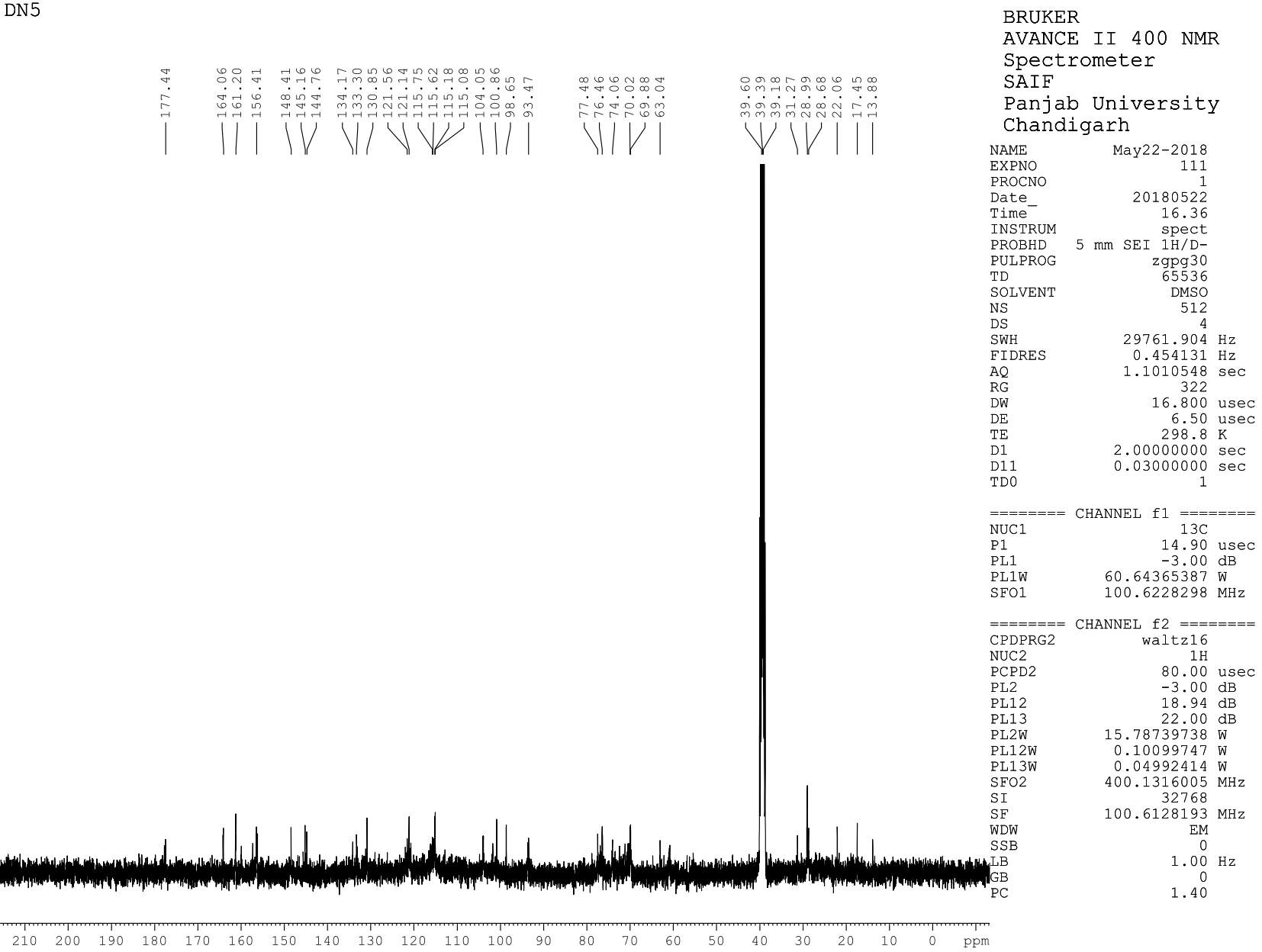

manishkumarmanu19860gmail.com

${ }^{13} \mathrm{C}$ NMR Spectrum of BF3

BF 3
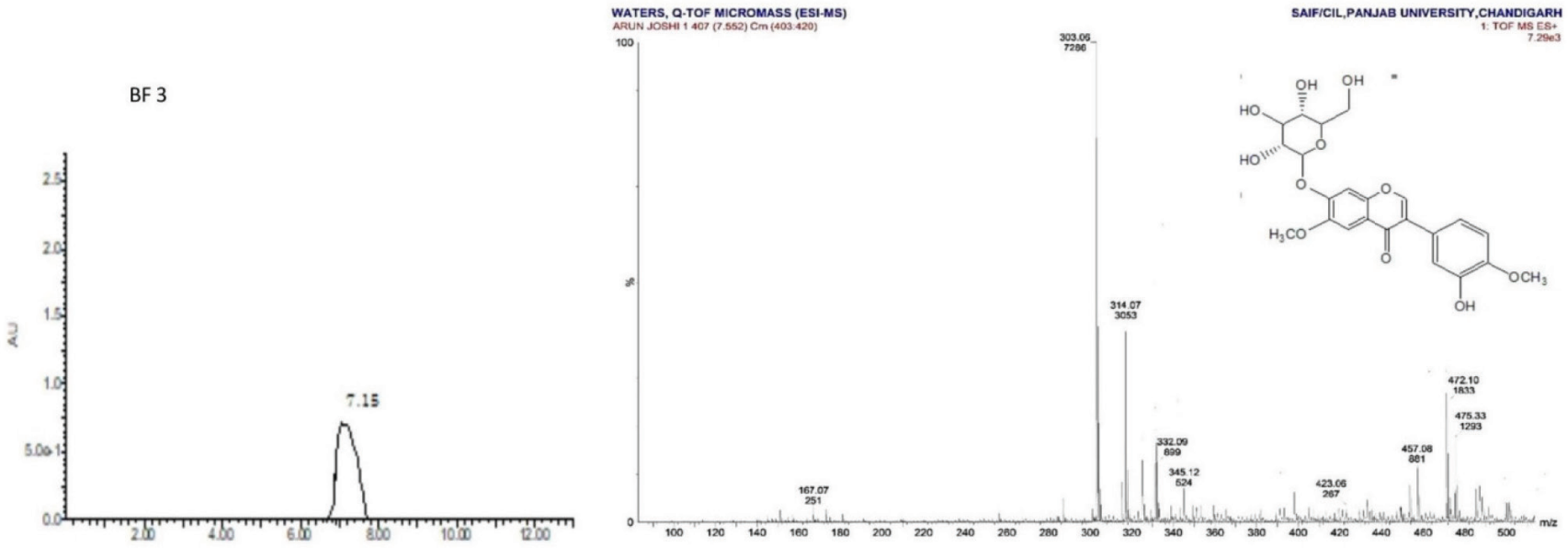

LC-MS Spectrum of BF 3 